\title{
AlPillin
}

AL-FIKRU: JURNAL PENDIDIKAN DAN SAINS, 2 (2), 2021 | e-ISSN 2774-5627 p-ISSN 2747-1349

\section{EFEKTIFITAS PROBLEM BASED LEARNING MENGGUNAKAN MEDIA SMARTPHONE DITINJAU DARI KEMAMPUAN KOGNITIF SISWA}

\author{
Loviga Denny Pratama ${ }^{1}$, Minggar Putra Dea Ramadhan² \\ ${ }^{1}$ Tadris Matematika, Universitas Islam Zainul Hasan Genggong \\ ${ }^{2}$ Teknik Informatika, Piliteknik Negeri Malang \\ ${ }^{1}$ loviga.pratama@gmail.com
}

\begin{abstract}
Currently, a technology media is needed in a mathematics learning process. However, some technological media such as smartphones are still not used optimally in creating a certain learning method in learning mathematics. This study aims to test the effectiveness of the Problem Based Learning (PBL) learning method facilitated by smartphone media by utilizing students' cognitive abilities. This study uses a quantitative approach (pretest-posttest with nonequivalent group design) with two treatments, namely the experimental class using the PBL method using Smartphone media and the control class using the Conventional PBL method. The subjects of this study were class VIII students who collected 63 students in the control class and 60 students in the experimental class. The effectiveness of the treatment in both classes was analyzed using the one sample t-test with a significance level of $5 \%$. The data from this study were analyzed using independent sample t-test with a significance level of 5\%. The results of this study indicate that $P B L$ using smartphone media is more effective than conventional PBL. Based on the results of this study, a new variation of the Problem Based Learning (PBL) method was found, namely this method can be done through face-to-face learning or online learning.
\end{abstract}

Keywords: Problem Based Learning, smartphone, insturctional media 


\section{PENDAHULUAN}

Era Industri 4.0 telah banyak merubah tampang pendidikan di Indonesia ini. Berbagai media-media berbasis teknologi telah banyak digunakan dalam suatu pembelajaran. Bahkan pemerintah Indonesia pun menganjurkan pengintegrasian teknologi dalam menunjang efisiensi dan efektifitas pembelajaran ${ }^{1}$. Terutama di era pandemi dan pasca pandemi COVID-19 ini sangat dibutuhkan pengintegrasian teknologi yang praktis serta fleksibel yang dapat digunakan dimana saja dan kapan saja, misalnya dapat berupa pembelajaran berbasis mobile atau perangkat seluler ${ }^{2}$.

Perangkat seluler adalah bagian dari kehidupan sehari-hari peserta didik di dalam dan di luar kelas. Teknik lain seperti kertas dan pensil serta program komputer juga dapat diterima. Meskipun demikian, sebagian besar generasi saat ini di tingkat sekolah maupun universitas tidak dapat melihat dunia tanpa teknologi seluler ${ }^{3}$. Sehingga berdasar pada kemajuan proses perubahan teknologi di bidang pendidikan, patut kita akui bahwa media berupa perangkat seluler dapat dipergunakan dari segala usia. Sehingga hal ini memungkinkan mereka untuk berinteraksi, bekerja sama, dan belajar melalui berbagai cara ${ }^{4}$.

Berdasarkan hasil penelitian sebelumnya, mengungkapkan bahwa guru matematika tertarik pada penggunaan perangkat seluler,

\footnotetext{
${ }^{1}$ Permendikbud, Peraturan Mentri Pendidikan Dan Kebudayaan Republik Indonesia Nomor 22 Tahun 2016 Tentang Standar Proses Pendidikan Dasar Dan Menengah (Jakarta: Kemendikbud, 2016).

${ }^{2}$ Loviga Denny Pratama, Wahyu Lestari, and Ika Astutik, "Efektifitas Penggunaan Media Edutainment Di Tengah Pandemi Covid-19," AKSIOMA: Jurnal Program Studi Pendidikan Matematika 9, no. 2 (2020).

${ }^{3}$ Jongpil Cheon et al., "An Investigation of Mobile Learning Readiness in Higher Education Based on the Theory of Planned Behavior," Computers and Education (2012).

4 Kevin Thomas and Marco Muñoz, "Hold the Phone! High School Students' Perceptions of Mobile Phone Integration in the Classroom.," American Secondary Education 44, no. 3 (2016).
} 
misalnya smartphone, dalam pembelajaran matematika ${ }^{5}$. Dari sudut pandang mereka, teknologi ini dapat meningkatkan motivasi dan partisipasi siswa dalam pembelajaran matematika serta memberikan berbagai cara dalam pengajaran matematika. Selain itu, motivasi siswa meningkat saat mereka menggunakan perangkat seluler. Studi lain menunjukkan bahwa pembelajaran dengan menggunakan perangkat seluler mendapatkan persepsi positif dari siswa, yakni "yang membuat matematika lebih dapat dipelajari, menyenangkan serta interaksional" 6 .

Hasil dari studi-studi tersebut, menunjukkan bahwa perangkat seluler tergolong layak untuk membantu dalam membuat konsep dan memahami konsep matematika. Lebih lanjut, perangkat seluler juga dapat digunakan untuk memunculkan lingkungan belajar kolaboratif, serta mempersempit kesenjangan antara materi matematika sekolah dengan kehidupan sehari-hari siswa; dibandingkan dengan buku sekolah ${ }^{7}$. Akibatnya, model matematika interaksional dari aplikasi perangkat seluler dapat memfasilitasi pembelajaran realistik di mana saja ${ }^{8}$.

Selain itu, lingkungan belajar yang mendorong siswa untuk mengumpulkan pengalaman praktis melalui hubungan dengan dunia nyata yang berkaitan dengan kehidupan sehari-hari siswa dapat meningkatkan kemampuan kognitif siswa dalam pembelajaran matematika ${ }^{9}$. Selain itu, media pembelajaran diperlukan untuk membantu siswa memahami konsep abstrak menjadi lebih konkrit dan meningkatkan kemampuan memahami matematika dan bereksplorasi

\footnotetext{
${ }^{5}$ Wahyu Lestari, Loviga Denny Pratama, and Wahyu Hidayatillah, "Persepsi Guru Dan Siswa Tentang Penggunaan Media Edutainment Di Tengah Pandemi Covid-19," Jurnal Pendidikan ... (2020).

${ }^{6}$ Supandi et al., "Mobile Phone Application for Mathematics Learning," in Journal of Physics: Conference Series, vol. 983, 2018.

${ }^{7}$ Thomas and Muñoz, "Hold the Phone! High School Students' Perceptions of Mobile Phone Integration in the Classroom."

${ }^{8}$ Linda Galligan et al., "The Use of Tablet and Related Technologies in Mathematics Teaching," Australian Senior Mathematics Journal 24, no. 1 (2010).

${ }^{9}$ Sefna Rismen, Ratulani Juwita, and Uchy Devinda, "Profil Kemampuan Pemecahan Masalah Matematika Siswa Ditinjau Dari Gaya Kognitif Reflektif," Jurnal Cendekia : Jurnal Pendidikan Matematika 4, no. 1 (2020).
} 
konsep matematika ${ }^{10}$. Oleh karena itu Pembelajaran Berbasis Masalah (PBL) menggunakan media smartphone menjadi salah satu pembelajaran yang direkomendasikan. PBL menggunakan masalah kehidupan nyata sebagai masalah pembelajaran utama, yang terkait dengan kehidupan nyata siswa yang dirasa perlu solusi ${ }^{11}$. Memproses informasi teori dan pembelajaran kolaboratif tersedia dalam kerangka teori PBL. Dalam gotong royong, siswa bekerja sama dari masalah untuk memahami, menerapkan konsep, menganalisis dan mengevaluasi langkah-langkah signifikan dari solusi dan menciptakan konsep baru dari proses pembelajaran ${ }^{12}$. Problem Based Learning dalam matematika sangat efektif dalam pembelajaran kognitif dimensi pengetahuan, pemahaman, dan aplikasi untuk siswa kelas VIII ${ }^{13}$.

Selain PBL, media smartphone berkontribusi dalam menyediakan pembelajaran yang interaktif dan dinamis ${ }^{14}$. Sehingga dapat memungkinkan siswa menerapkan latihan, masalah dan tugas, serta mengembangkan kemampuan siswa dalam pembelajaran matematika. Selain itu, aplikasi-aplikasi berupa media pembelajaran yang disediakan oleh perangkat seluler, lebih memudahkan siswa dalam memahami materi dibandingkan dengan metode konvensional yang saat ini diterapkan dalam pengajaran matematika ${ }^{15}$. Bahkan karena pentingnya teknologi perangkat seluler dalam pengajaran matematika,

10 Vivin Nur Afidah, "PRINSIP- PRINSIP TEORI BEBAN KOGNITIF DALAM MERANCANG MEDIA PEMBELAJARAN MATEMATIKA,” JP2M (Jurnal Pendidikan dan Pembelajaran Matematika) 1, no. 2 (2020).

11 Ali Syamsuri, Ika Wahyu Anita, and Heris Hendriana, "PENERAPAN PENDEKATAN PROBLEM BASED LEARNING UNTUK MENINGKATKAN KEMAMPUAN BERPIKIR KRITIS SISWA SMP," JPMI (Jurnal Pembelajaran Matematika Inovatif) 2, no. 5 (2019).

${ }^{12}$ Sandha Soemantri, "PBL Dengan Pendekatan Realistic Mathematic Meningkatkan Nilai Karakter Siswa Berkebutuhan Khusus," Math Didactic: Jurnal Pendidikan Matematika (2019).

${ }^{13}$ Ruhban Maskur et al., "The Effectiveness of Problem Based Learning and Aptitude Treatment Interaction in Improving Mathematical Creative Thinking Skills on Curriculum 2013," European Journal of Educational Research 9, no. 1 (2020).

${ }^{14}$ Lina Dias and Angelin Victor, "Teaching and Learning with Mobile Devices in the 21st Century Digital World: Benefits and Challenges," European Journal of Multidisciplinary Studies 5, no. 1 (2017).

15 Ros Walker, “'I Don't Think i Would Be Where i Am Right Now'. Pupil Perspectives on Using Mobile Devices for Learning," Research in Learning Technology 21 (2013). 
National Council of Teachers Mathematics (NCTM) menyerukan untuk membangun kebijakan pendidikan yang memanfaatkan teknologi dalam pengajaran matematika melalui penggunaan perangkat smartphone ${ }^{16}$. Dengan demikian, siswa menerima program pengajaran matematika secara luas, karena kemampuan teknologi untuk mempromosikan pembelajaran siswa melalui perwujudan ide matematika dalam bentuk yang terlihat. Mereka, juga, memfasilitasi organisasi data, penyimpanan, analisis dan pengambilan dengan cara yang berbeda, dan menerapkan operasi aritmatika dengan akurasi dan efisiensi. Oleh karena itu, NCTM (2000) mengadopsi teknologi dalam prinsip-prinsip yang mendasari matematika sekolah.

Berdasarkan uraian tersebut, maka pelaksanaan pembelajaran berbasis masalah (PBL) menggunakan media smartphone penting untuk diterapkan. Terlebih lagi, saat ini di Indonesia mulai terbiasa melakukan pembelajaran via Daring. Dimana tentunya suatu penggunaan tekhnologi akan berperan penting. Sehingga melalui pembelajaran berbasis masalah dengan menggunakan media smartphone diharapkan dapat membantu siswa menemukan solusi untuk penyelesaian masalah kontekstual yang diangkat dalam pembelajaran dan meningkatkan kemampuan kognitif siswa. Sehingga studi ini bertujuan untuk mengetahui keefektifitas model Problem Based Learning (PBL) dengan menggunakan media smartphone ditinjau dari kemampuan kognitif siswa.

\section{METODE}

Studi ini menggunakan pendekatan kuantitatif dengan desain penelitian quasi-experiment dengan menggunakan Pretest Posttest Nonequivalent Control Group Design. Adapun pelaksanaanya, studi ini menggunakan dua perlakuan yang berbeda yakni kelas kontrol dan kelas eksperimen. Kelas kontrol yang digunakan yakni melakukan pembelajaran berbasis masalah (PBL) konvensional, yakni dibantu dengan buku teks Kurikulum 2013. Sedangkan Kelas eksperimen melakukan pembelajaran berbasis masalah (PBL) dengan menggunakan media smartphone. Adapun subyek penelitian ini adalah

16 Mary M. Lindquist and James D. Gates, "National Council of Teachers of Mathematics," Teaching Children Mathematics 1, no. 1 (2020). 
siswa kelas VIII yang berjumlah 63 siswa di kelas kontrol dan 60 siswa di kelas eksperimen.

Teknik pengumpulan data dalam penelitian ini adalah dengan memberikan pretest dan posttest pada kelas eksperimen dan kelas kontrol. Tes diberikan untuk menilai kemampuan kognitif matematis siswa dalam materi Peluang untuk siswa SMP kelas VIII. Pretest dan posttest kemampuan kognitif menggunakan Taksonomi Bloom dalam kemampuan kognitif siswa, yang terdiri dari 18 item termasuk 12 pilihan ganda (mengingat, memahami, dan mengaplikasikan) dan 6 uraian tes (menganalisis, mengevaluasi, dan mecipta). Instrumen ini telah melalui proses validitas oleh tiga expert judgement. Adapun validitas konstruk kemampuan kognitif pada posttest dan pretest dalam kategori sedang (Mean $\mathrm{P}=0,635$ untuk pretest; dan Mean $\mathrm{P}=0,612$ untuk Posttest) ${ }^{17}$. Diskriminasi item untuk pilihan ganda pretest cukup baik $($ Rpbis $=0,376)$ dan juga untuk posttest pilihan ganda $($ Rpbis $=$ 0,393). Adapun reliabilitas untuk pretest kemampuan kognitif memberikan Cronbach's Alpha $=0,767$ untuk pilihan ganda dan Cronbach's Alpha $=0,832$ untuk tes deskripsi. Sedangkan reliabilitas untuk posttest kemampuan kognitif diperoleh Cronbach's Alpha = 0,733 untuk pilihan ganda dan Cronbach's Alpha $=0,896$ untuk soal uraian.

Penelitian ini berlangsung selama enam minggu, baik untuk kelas kontrol dan kelas eksperimen. Rincian untuk pembelajaran kelompol kontrol yakni menggunakan sintaks PBL dengan seluruh pertemuaannya menggunakan buku pembelajaran Kurikulum 2013. Sedangkan pembelajaran kelompok eksperimen menggunakan sintaks PBL dengan seluruh pertemuannya menggunakan media smartphone. Adapun Rincian pengaturan pembelajaran untuk kelas eksperimen ditunjukkan pada Tabel 1 berikut.

Tabel 1. Pengaturan Pembelajaran Kelompok Eksperimen

\begin{tabular}{ccc}
\hline Minggu & $\begin{array}{c}\text { Media } \\
\text { Pembelajaran }\end{array}$ & Menggunakan Software \\
\hline
\end{tabular}

Minggu ke-1 smartphone platform LMS (online)

17 A. J. Nitko and S. M. Brookhart, Educational Asessment of Student (Columbus: Prentice Hall, 2011). 


$\begin{array}{lll}\text { Minggu ke-2 } & \text { smartphone } & \text { Platform Kahoot! } \\ \text { Minggu ke-3 } & \text { Smartphone } & \text { Game Edukasi } \\ \text { Minggu ke-4 } & \text { Smartphone } & \text { Game Edukasi } \\ \text { Minggu ke-5 } & \text { Smartphone } & \text { Youtube } \\ \text { Minggu ke-6 } & \text { smartphone } & \text { Platform Quizizz }\end{array}$

Data dianalisis dengan menguji normalitas dan homogenitas data diperoleh dari hasil pretest dan posttest kedua kelas. Uji normalitas menggunakan Kolmogorov-Smirnov, sedangkan uji homogenitas menggunakan statistik Levene. Satu sampel t-test digunakan untuk menentukan pengaruh PBL dengan penggunaan media smartphone (kelas eksperimen) dan PBL konvensional (kelas kontrol) dalam kemampuan kognitif matematis siswa. Sedang kelas kontrol dan eksperimen dikatakan efektif jika nilai rata-rata $(\mu)>75$. Adapun uji independent sample t-test juga digunakan untuk mengetahu hasil yang lebih efektif antara kedua perkaluan tersebut.

\section{Hasil}

\section{HASIL DAN PEMBAHASAN}

Temuan penelitian ini didasarkan pada data eksperimen yang dikumpulkan dari responden. Dua tes (pretest dan posttes) yang telah dilakukan kemudian dianalisis menggunakan software SPSS 21. Hasil analisis perbandingan rata-rata tes tersebut antara PBL konvensional dengan kelas PBL menggunakan media smartphone ditunjukkan secara deskriptif pada Tabel 2.

Tabel 2. Hasil Analisis Pretest dan Postest pada Kelas Kontrol dan Eksperimen

\begin{tabular}{ccccc}
\hline Jenis Tes & Perlakuan & n & M & SD \\
\hline \multirow{2}{*}{ Pretest } & PBL dengan media smartphone & 60 & 29,86 & 7,27 \\
\cline { 2 - 5 } & PBL & 63 & 27,42 & 8,32 \\
\hline \multirow{2}{*}{ Posttest } & PBL dengan media smartphone & 60 & 84,75 & 5,21 \\
\cline { 2 - 5 } & PBL & 63 & 79,82 & 7,43 \\
\hline
\end{tabular}


Nilai signifikansi pada uji Kolmogorov-Smirnov kemampuan kognitif siswa pada pretest mendapatkan skor >0,05 untuk kelas eksperimen $(p$-value $=0,061)$ dan kelas kontrol $(p$-value $=0,212)$. Hal ini dapat dikatakan bahwa data pretest berdistribusi normal. Sedangkan pada nilai signifikansi uji homogenitas varians pada Levene pada data pretest adalah 0,321 lebih besar dari 0,05. Uji asumsi yang terpenuhi meliputi uji normalitas dan uji homogenitas untuk data pretest, sehingga perlakuan pada kedua kelas dalam penelitian ini dapat diterapkan. Adapun nilai signifikansi pada uji Kolmogorov-Smirnov kemampuan kognitif siswa pada data posttest juga mendapatkan skor $>0,05$ untuk kelas eksperimen ( $p$-value $=0,213$ ) dan kelas kontrol ( $p$-value $=0,241)$. Hal ini berarti data posttest juga berdistribusi normal. Sedangkan nilai signifikansi uji homogenitas varians pada Levene pada data posttest adalah 0,921 lebih besar dari 0,05. Hal ini dapat dikatakan bahwa uji asumsi meliputi uji normalitas dan uji homogenitas untuk data posttest telah terpenuhi, sehingga one sample t-test pada kedua kelas dalam penelitian ini dapat diterapkan.

Meningkatnya aktivitas belajar di dalam kelas berdampak positif bagi kemampuan kognitif siswa dalam pembelajaran matematika. Pada studi ini kemampuan kognitif kedua kelas ditemukan efektif dari hasil uji one sample t-test. Terlihat setelah perlakuan (data posttest) menunjukkan nilai signifikansi $<0,05$. Adapun rincian hasil one sample t-test ditunjukkan pada Tabel 3 .

Tabel 3. Hasil Analisis One Sample T-Test Kelas Kontrol dan Eksperimen

\begin{tabular}{cccc}
\hline Perlakuan & n & t & Sig. \\
\hline PBL dengan media smartphone & 60 & 5.46 & 0.00 \\
PBL & 63 & 3.22 & 0.023 \\
\hline
\end{tabular}

Berdasarkan Tabel 3 diperoleh nilai signifikansi variabel kemampuan kognitif dalam pembelajaran matematika siswa sebesar kurang dari 0,05. Hal ini menunjukkan bahwa perlakuan PBL dengan media smartphone dan PBL konvensional, keduanya efektif ditinjau dari kemampuan kognitif siswa dalam pembelajaran matematika. Berdasarkan hasil uji independent sample t-test diperoleh nilai signifikansi hasil untuk kemampuan kognitif $=0,0234<0,05(\mathrm{t}=$ 2,153). Artinya pembelajaran berbasis masalah dengan penggunaan 
media smartphone lebih efektif dibandingkan pembelajaran berbasis masalah konvensional terhadap kemampuan kognitif matematis.

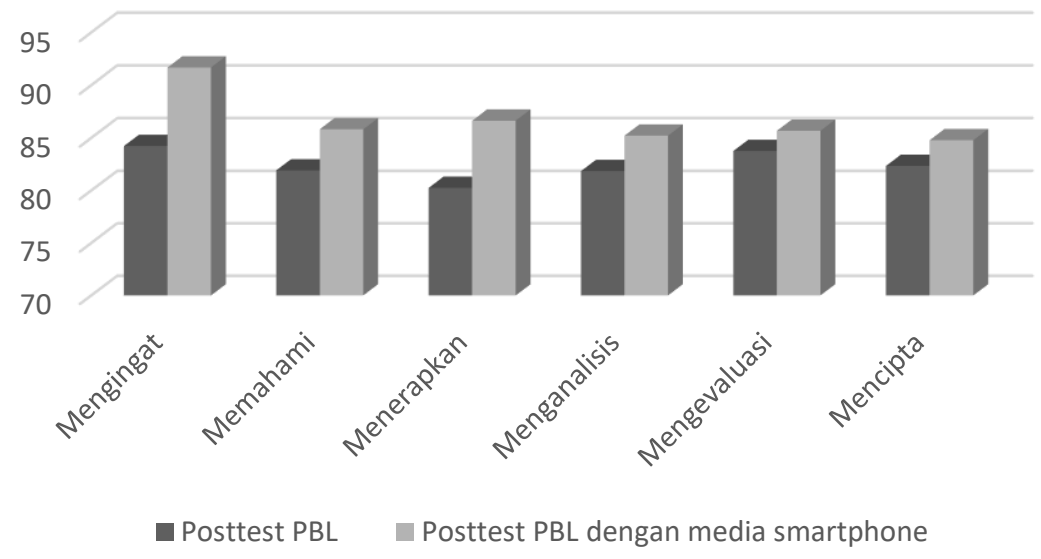

Gambar 1. Grafik Persentasi Kemampuan Kognitif Siswa

Deskripsi kemampuan kognitif siswa pada tes pilihan ganda dianalisis berdasarkan kemampuan kognitif siswa meliputi mengingat, memahami dan mengaplikasikan. Sedangkan deskripsi kemampuan kognitif dalam tes uraian deskripsi menunjukkan kemampuan siswa meliputi aspek menganalisis, mengevaluasi dan mencipta. Berdasarkan Gambar 1, secara umum persentase kemampuan kognitif siswa pada kelas PBL yang menggunakan media smartphone lebih baik dibandingkan dengan kelas PBL konvensional. Melalui hal ini juga kita ketahui bahwa, pembelajaran matematika dengan menggunakan metode PBL mendukung peningkatan kemampuan kognitif siswa melalui representasi konkret dari masalah abstrak. Hal ini terlihat bahwa hanya dengan menggunakan metode PBL telah memberikan $84,23 \%$ pada kemampuan mengingat $(\mathrm{C} 1), 81,92 \%$ pada kemampuan pemahaman siswa (C2), 80,25\% pada kemampuan menerapkan (C3), dan $82,34 \%$ pada kemampuan mencipta (C6).

Selain pembelajaran berbasis masalah (PBL), penggunaan media smartphone juga mendukung peningkatan kemampuan kognitif siswa melalui representasi konkret dari masalah abstrak dalam matematika. Media smartphone ternyata dapat memfasilitasi siswa untuk menerjemahkan konsep matematika ke dalam bentuk yang lebih nyata dan memungkinkan mereka untuk menghubungkan pengetahuan baru dengan pengetahuan yang ada. Sehingga berdasarkan Gambar 1, 
penelitian ini menemukan bahwa PBL dengan menggunakan media smartphone berpengaruh positif terhadap kemampuan kognitif dalam memahami masalah (mengingat dan memahami), dan memecahkan masalah (menganalisis dan mengevaluasi) pengetahuan prosedural dan pengetahuan konseptual. PBL dengan media smartphone memberikan 91,67\% pada kemampuan mengingat siswa, 85,82\% pada kemampuan pemahaman siswa, 86,63\% pada kemampuan menerapkan konsep, 85,21 pada kemampuan menganalisis, 85,67 pada kemampuan mengevaluasi dan $84,78 \%$ pada kemampuan mencipta.

\section{Pembahasan}

Berdasarkan hasil pada studi ini, menunjukkan tingkat deskriptif kemampuan kognitif secara keseluruhan di dua perlakuan, yakni PBL menggunakan media smartphone dan PBL konvensional. Secara parsial, Data posttest diperoleh bahwa PBL menggunakan media smartphone dan PBL konvensional berpengaruh positif terhadap profitabilitas kinerja siswa. Di samping itu, PBL dengan media smartphone mendapatkan nilai lebih baik daripada kelas PBL. Hal ini juga dikarenakan karakteristik PBL seperti pembelajaran kolaboratif dalam kelompok kecil, mengaktifkan pengetahuan awal melalui diskusi kelompok, memiliki pemahaman awal untuk memfasilitasi pembelajaran, dan memiliki sumber daya untuk membantu mereka memecahkan masalah yang diberikan sesuai dengan arsitektur kognitif siswa $^{18}$.

Pada studi ini, masalah matematika yang dikerjakan siswa yakni berkaitan dengan kontekstual dan dalam lembar kerja siswa. Sebagai contoh, siswa diminta untuk menemukan solusi dan kesimpulan tentang membandingkan probabilitas teoritis dan eksperimental. Masalah yang diberikan adalah untuk menentukan siapa yang memiliki peluang terbesar untuk 4 calon dari 40 siswa yang dipilih untuk menjadi ketua kelas. Siswa menggunakan satu bola merah sebagai calon pertama, satu bola kuning sebagai calon kedua, dan satu bola biru sebagai calon ketiga dan mengambil 40 secara acak untuk mendapatkan nilai probabilitas eksperimen dan membandingkan dengan nilai probabilitas teoritis untuk mendapatkan kesimpulan. Artinya melalui penggunaan

${ }^{18}$ Soemantri, "PBL Dengan Pendekatan Realistic Mathematic Meningkatkan Nilai Karakter Siswa Berkebutuhan Khusus." 
media smartphone dapat dengan mudah menjadikan hal yang abstrak tersebut menjadi sesuatu yang kongkret dipahami siswa. Karena dalam pembelajaran menggunakan smartphone, kita dengan mudah dalam memunculkan gambar, simbol, mapun video ${ }^{19}$. Selain itu, pada penggunaan smartphone juga dengan mudah memunculkan hubungan antara objek dengan ide-ide matematika yang digambarkan melalui video $^{20}$.

Lebih lanjut, dengan menggunakan PBL yang difasilitasi oleh media smartphone, dapat memfasilitasi siswa untuk menafsirkan pemikiran matematika mereka, mewakili hubungan antara ide-ide matematika dan mengembangkan konten yang sesuai untuk belajar matematika ${ }^{21}$. Selain itu, sejalan dengan penelitian terdahulu yang menyatakan bahwa belajar dengan menggunakan media smartphone dalam matematika, siswa mampu mengembangkan pengetahuan konseptual, memfasilitasi materi konkret dalam matematika, membuat dalam mempermudah memahami dan memecahkan masalah dalam pembelajarannya ${ }^{22}$. Bahkan melalui media smartphone dapat memfasilitasi siswa untuk menganalisis informasi tentang konsepkonsep matematika yang telah mereka pelajari sebelumnya, dengan informasi yang baru saja mereka peroleh untuk menentukan solusi dari suatu masalah yang diberikan.

Namun demikian, terdapat kelemahan-kelemahan dalam menggunakan metode PBL berdasarkan studi terdahulu. Alokasi waktu yang cukup banyak dibandingkan pembelajaran konvensional ${ }^{23}$ serta

\footnotetext{
${ }^{19}$ Chairul Fajar Tafrilyanto and Moh. Zayya Harfin, "Desain Pembelajaran Statistik Melalui Google Classroom," Jurnal Pembelajaran Matematika Inovatif 3, no. 6 (2020).

${ }^{20}$ Widyasari Widyasari, Hadi Sutopo, and Murniati Agustian, "QR Code-Based Learning Development: Accessing Math Game for Children Learning Enhancement," International Journal of Interactive Mobile Technologies 13, no. 11 (2019): 111-124. ${ }^{21}$ Loviga Denny Pratama and W. Setyaningrum, "GBL in Math Problem Solving: Is It Effective?," International Journal of Interactive Mobile Technologies (iJIM) 12, no. 6 (2018): 101.

${ }^{22}$ Loviga Denny Pratama and W. Setyaningrum, "Game-Based Learning: The Effects on Student Cognitive and Affective Aspects," Journal of Physics: Conference Series 1097, no. 1 (2018).

${ }^{23}$ M. Ali Ghufron and Siti Ermawati, "The Strengths and Weaknesses of Cooperative Learning and Problem-Based Learning in EFL Writing Class: Teachers and Students' Perspectives," International Journal of Instruction (2018).
} 
PBL sangat sulit memberikan pengaruh signifikan jika dilakukan pada waktu yang cukup singkat ${ }^{24}$ masih menjadi kelemahan yang sering ditemukan. Namun, dengan menggunakan media berupa smartphone, kelemahan tersebut bisa diminimalisir. Hal ini dikarenakan media smartphone memberikan ruang yang cukup luas dalam melakukan analisis masalah, belajar mandiri, bahkan dalam memahami materi ${ }^{25}$

Adapun modifikasi pada studi ini dapat menambahkan variasi bari dari metode Problem Based Learning (PBL), yakni metode ini ternyata dapat dilakukan melalui pembelajaran tatap muka maupun pembelajaran via online. Hal ini juga berdasar pada pembelajaran dengan menggunakan smartphone akan saling mendukung dalam kegiatan pembelajaran tatap muka maupun via online ${ }^{26}$. Terlebih lagi, penggunaan media smartphone dalam suatu pembelajaran, beberapa penelitian terdahulu mengungkapkan implikasinya terhadap prestasi belajar siswa. Salah satunya, penggunaan media smartphone dalam suatu pembelajaran matematika, akan mempengaruhi peningkatan prestasi belajar siswa ${ }^{27}$.

\section{PENUTUP}

Berdasarkan hasil dari studi ini, menunjukkan bahwa PBL menggunakan media smartphone lebih efektif daripada PBL konvensional. Penerapan PBL dengan menggunakan media smartphone dalam pembelajaran matematika memberikan pengalaman kepada siswa untuk meningkatkan kemampuan kognitifnya sehingga model tersebut dapat diterapkan dalam proses pembelajaran. Masalah kehidupan nyata mendukung siswa untuk berperan aktif dalam proses pembelajaran melalui penggunaan masalah yang berkaitan dengan

\footnotetext{
${ }^{24}$ Soemantri, "PBL Dengan Pendekatan Realistic Mathematic Meningkatkan Nilai Karakter Siswa Berkebutuhan Khusus."

25 Pratama, Lestari, and Astutik, "Efektifitas Penggunaan Media Edutainment Di Tengah Pandemi Covid-19."

26 W. Lestari, Loviga Denny Pratama, and Lifia Sulistiowati, "EFEKTIFITAS PEMBELAJARAN BERBASIS M-PBL DALAM MENUNJANG PEMBELAJARAN MATEMATIKA SECARA DARING," Jurnal Magister Pendidikan Matematika (JUMADIKA) 3, no. 1 (2021).

${ }^{27}$ Lestari, Pratama, and Hidayatillah, "Persepsi Guru Dan Siswa Tentang Penggunaan Media Edutainment Di Tengah Pandemi Covid-19"; Loviga Denny Pratama, A. Bahauddin, and W. Lestari, "Game Edukasi: Apakah Membuat Belajar Lebih Menarik?," At- Ta'lim 5, no. 1 (2019): 39-50.
} 
kehidupan sehari-hari mereka karena masalah ini akan menuntut siswa untuk menemukan data, berpikir untuk merancang solusi dan memecahkan masalah. Selain itu, melalui PBL mengkolaborasikan pekerjaan rumah siswa bersama-sama dalam kelompok kecil. Kolaborasi memberikan motivasi untuk terus terlibat dalam tugas-tugas kompleks dan memperluas kesempatan untuk berbagi penyelidikan dan dialog dan untuk mengembangkan keterampilan sosial dan keterampilan berpikir.

PBL dengan menggunakan media smartphone juga akan membuat guru mata pelajaran lebih kreatif dan inovatif dalam merencanakan proses pembelajaran matematika di kelas. Guru dituntut untuk mengaplikasikan permasalahan di dunia nyata dan dapat memunculkannya melalui aplikasi-aplikasi pada media smartphone sebagai simbol dari konsep abstrak yang ada pada permasalahan. Sehingga membuat masalah-masalah kontekstual pada matematika akan terasa lebih bermakna pada diri siswa.

\section{DAFTAR PUSTAKA}

Afidah, Vivin Nur. "PRINSIP- PRINSIP TEORI BEBAN KOGNITIF DALAM MERANCANG MEDIA PEMBELAJARAN MATEMATIKA." JP2M (Jurnal Pendidikan dan Pembelajaran Matematika) 1, no. 2 (2020).

Cheon, Jongpil, Sangno Lee, Steven M. Crooks, and Jaeki Song. “An Investigation of Mobile Learning Readiness in Higher Education Based on the Theory of Planned Behavior." Computers and Education (2012).

Dias, Lina, and Angelin Victor. "Teaching and Learning with Mobile Devices in the 21st Century Digital World: Benefits and Challenges." European Journal of Multidisciplinary Studies 5, no. 1 (2017).

Galligan, Linda, Birgit Loch, Christine McDonald, and Janet A. Taylor. "The Use of Tablet and Related Technologies in Mathematics Teaching." Australian Senior Mathematics Journal 24, no. 1 (2010).

Ghufron, M. Ali, and Siti Ermawati. "The Strengths and Weaknesses of Cooperative Learning and Problem-Based Learning in EFL Writing Class: Teachers and Students' Perspectives." 
International Journal of Instruction (2018).

Lestari, W., Loviga Denny Pratama, and Lifia Sulistiowati. "EFEKTIFITAS PEMBELAJARAN BERBASIS M-PBL DALAM MENUNJANG PEMBELAJARAN MATEMATIKA SECARA DARING." Jurnal Magister Pendidikan Matematika (JUMADIKA) 3, no. 1 (2021).

Lestari, Wahyu, Loviga Denny Pratama, and Wahyu Hidayatillah. "Persepsi Guru Dan Siswa Tentang Penggunaan Media Edutainment Di Tengah Pandemi Covid-19." Jurnal Pendidikan ... (2020).

Lindquist, Mary M., and James D. Gates. "National Council of Teachers of Mathematics." Teaching Children Mathematics 1, no. 1 (2020).

Maskur, Ruhban, Sumarno, Yasinta Rahmawati, Kenny Pradana, Muhamad Syazali, Ari Septian, and Endah Kinarya Palupi. "The Effectiveness of Problem Based Learning and Aptitude Treatment Interaction in Improving Mathematical Creative Thinking Skills on Curriculum 2013." European Journal of Educational Research 9, no. 1 (2020).

Nitko, A. J., and S. M. Brookhart. Educational Asessment of Student. Columbus: Prentice Hall, 2011.

Permendikbud. Peraturan Mentri Pendidikan Dan Kebudayaan Republik Indonesia Nomor 22 Tahun 2016 Tentang Standar Proses Pendidikan Dasar Dan Menengah. Jakarta: Kemendikbud, 2016.

Pratama, Loviga Denny, A. Bahauddin, and W. Lestari. "Game Edukasi: Apakah Membuat Belajar Lebih Menarik?” At- Ta'lim 5, no. 1 (2019): 39-50.

Pratama, Loviga Denny, Wahyu Lestari, and Ika Astutik. "Efektifitas Penggunaan Media Edutainment Di Tengah Pandemi Covid-19." AKSIOMA: Jurnal Program Studi Pendidikan Matematika 9, no. $2(2020)$.

Pratama, Loviga Denny, and W. Setyaningrum. "Game-Based Learning: The Effects on Student Cognitive and Affective Aspects." Journal of Physics: Conference Series 1097, no. 1 (2018).

- "GBL in Math Problem Solving: Is It Effective?" International Journal of Interactive Mobile Technologies (iJIM) 12, no. 6 (2018): 101.

Rismen, Sefna, Ratulani Juwita, and Uchy Devinda. "Profil 
Kemampuan Pemecahan Masalah Matematika Siswa Ditinjau

Dari Gaya Kognitif Reflektif." Jurnal Cendekia: Jurnal

Pendidikan Matematika 4, no. 1 (2020).

Soemantri, Sandha. "PBL Dengan Pendekatan Realistic Mathematic

Meningkatkan Nilai Karakter Siswa Berkebutuhan Khusus." Math

Didactic: Jurnal Pendidikan Matematika (2019).

Supandi, L. Ariyanto, W. Kusumaningsih, and A. N. Aini. "Mobile

Phone Application for Mathematics Learning." In Journal of

Physics: Conference Series. Vol. 983, 2018.

Syamsuri, Ali, Ika Wahyu Anita, and Heris Hendriana. "PENERAPAN

PENDEKATAN PROBLEM BASED LEARNING UNTUK MENINGKATKAN KEMAMPUAN BERPIKIR KRITIS

SISWA SMP." JPMI (Jurnal Pembelajaran Matematika Inovatif) 2, no. 5 (2019).

Tafrilyanto, Chairul Fajar, and Moh. Zayya Harfin. "Desain

Pembelajaran Statistik Melalui Google Classroom." Jurnal Pembelajaran Matematika Inovatif 3, no. 6 (2020).

Thomas, Kevin, and Marco Muñoz. "Hold the Phone! High School

Students' Perceptions of Mobile Phone Integration in the

Classroom." American Secondary Education 44, no. 3 (2016).

Walker, Ros. "II Don't Think i Would Be Where i Am Right Now'.

Pupil Perspectives on Using Mobile Devices for Learning."

Research in Learning Technology 21 (2013).

Widyasari, Widyasari, Hadi Sutopo, and Murniati Agustian. "QR CodeBased Learning Development: Accessing Math Game for Children Learning Enhancement." International Journal of Interactive Mobile Technologies 13, no. 11 (2019): 111-124. 